\title{
ANALISIS EFISIENSI PEMASARAN JAGUNG DI PROVINSI GORONTALO
}

\author{
Ulfira Ashari1 dan Syamsir ${ }^{2}$ \\ 1,2) Program Studi Agribisnis, Fakultas Pertanian, Universitas Ichsan Gorontalo \\ Jl. Drs. Achmad Nadjamuddin No. 17, Kota Gorontalo, Indonesia \\ e-mail: 1)ulfira1989@gmail.com
}

(Diterima 9 September 2020/Revisi 25 Oktober 2020 /Disetujui 16 November 2020)

\begin{abstract}
Price fluctuations at the producer and consumer levels determine the performance of the maize market in Gorontalo Province. This will affect the decisions and ability of the corn marketing agencies involved in responding to price changes. The slow response of marketing agencies to changes in maize prices indicates inefficient market conditions in terms of prices. In addition, differences in market power between marketing agencies indicate inefficiencies in marketing maize from an operational perspective. Therefore, this research was conducted with the aim of 1) analyzing market integration and transmission of maize prices between producers and consumers, 2) analyzing the distribution of marketing margins in the maize marketing channels in Gorontalo Province. The research data used is in the form of weekly price data at the producer and consumer levels for 148 weeks, from March 2016 to March 2019 and added data from direct interviews with the marketing actors involved, namely farmers as many as 30 people, while sampling of traders was carried out by snowball sampling technique. Data analysis used the Asymmetric Error Correction Model $(A E C M)$, marketing margin and farmer share for each channel. The results showed that the transmission of maize prices at the producer and consumer level is symmetrical in the long run indicating market integration. The smallest marketing margin and the largest farmer share are in Channel III, where marketing is done directly to an exporter. Corn marketing in Gorontalo Province shows price transmission and market integration as well as high farmer share value in each channel, so it can be concluded that marketing is efficient.
\end{abstract}

Keywords: corn price, efficiency, market integration, margin

\begin{abstract}
ABSTRAK
Fluktuasi harga di tingkat produsen dan konsumen menentukan kinerja pasar jagung di Provinsi Gorontalo. Hal tersebut akan mempengaruhi keputusan dan kemampuan lembaga pemasaran jagung yang terlibat dalam merespon perubahan harga. Lambatnya respon lembaga pemasaran terhadap perubahan harga jagung mengindikasikan kondisi pasar yang tidak efisien dari segi harga. Selain itu, perbedaan market power antar lembaga pemasaran mengindikasikan inefisiensi dalam pemasaran jagung dari segi operasional. Oleh karena itu, penelitian ini dilakukan dengan tujuan untuk 1) menganalisis integrasi pasar dan transmisi harga jagung antara produsen dan konsumen, 2) menganalisis penyebaran marjin pemasaran pada saluran pemasaran jagung di Provinsi Gorontalo. Data penelitian yang digunakan berupa data time series harga mingguan di tingkat produsen dan konsumen selama 148 minggu yaitu dari bulan Maret 2016 hingga Maret 2019 serta ditambahkan data dari wawancara langsung dengan pelaku pemasaran yang terlibat yakni petani sebanyak 30 orang, sedangkan pengambilan sampel pedagang dilakukan dengan teknik snowball sampling berdasarkan alur pemasaran yang ada di Kabupaten Pohuwato. Analisis data menggunakan Asymmetric Error Correction Model (AECM), marjin pemasaran dan farmer share tiap saluran. Hasil penelitian menunjukkan bahwa transmisi harga jagung di tingkat produsen dan konsumen bersifat simetri dalam jangka panjang mengindikasikan terjadinya integrasi pasar. Marjin pemasaran terkecil dan farmer share terbesar berada pada Saluran III, dimana pemasaran ke eksportir dilakukan secara langsung. Pemasaran jagung di Provinsi Gorontalo menunjukkan adanya transmisi harga dan integrasi pasar serta nilai farmer share yang tinggi pada tiap saluran, sehingga disimpulkan bahwa pemasaran bersifat efisien.
\end{abstract}

Kata kunci: efisiensi, harga jagung, integrasi pasar, marjin 


\section{PENDAHULUAN}

Jagung merupakan komoditi pangan unggulan Provinsi Gorontalo digunakan sebagai bahan baku industri rumah tangga dalam pembuatan produk olahan jagung misalnya emping jagung, stik jagung, dan produk lainnya. Selain itu, jagung juga dimanfaatkan sebagai pakan ternak dan produk ekspor. Oleh karena itu, adanya fluktuasi produksi jagung akan mempengaruhi permintaan dan penawaran jagung. Badan Pusat Statistik (2016) mencatat produksi tertinggi terjadi pada tahun 2014 sebesar 719.780 ton dan mengalami penurunan produksi pada tahun 2015 disebabkan karena adanya penurunan luas panen jagung sebanyak 13,23 persen.

Salah satu faktor yang mempengaruhi fluktuasi produksi jagung adalah musim. Pasokan jagung melimpah saat panen raya tetapi tidak diikuti dengan peningkatan permintaan jagung sehingga menyebabkan harga jagung menjadi turun. Kondisi tersebut merugikan bagi petani sebagai produsen jagung tetapi menguntungkan bagi konsumen karena dapat membeli jagung dengan harga yang lebih murah (Purwasih, Firdaus, \& Hartoyo, 2017). Harga yang terbentuk di pasaran harusnya mampu memberikan kepuasan kepada setiap lembaga pemasaran yang terlibat. Artinya setiap lembaga mendapatkan keuntungan dari transaksi yang dilakukan berdasarkan harga yang telah disepakati. Kenyataannya masih terdapat disparitas harga jagung dari produsen hingga ke tangan konsumen dipengaruhi besarnya biaya produksi dan biaya pemasaran jagung yang timbul akibat fungsi pemasaran yang terjadi meliputi fungsi pertukaran, fisik dan fasilitas (Firdaus, 2009; Rahmi \& Arif, 2012; Astuti, Maharani, \& Yusmini, 2016).

Produksi secara tidak langsung mempengaruhi perubahan harga jagung. Kenaikan jumlah produksi menyebabkan peningkatan jumlah penawaran jagung. Apabila penawaran meningkat maka harga jagung akan turun, begitu pula sebaliknya (Surbakti, Darus, \& Chalil, 2015). Maka dari itu, efisiensi harga dapat tercapai apabila masing-masing pihak yang terlibat dalam pemasaran responsif terhadap perubahan harga yang berlaku, terdapat peningkatan nilai guna produk, dan terkordinasinya aktivitas mulai dari petani, lembaga pemasaran dan konsumen (Asmarantaka, 2012).

Transmisi harga menjadi syarat penting terwujudnya integrasi pasar antara tingkat produsen dan konsumen (Kusumaningsih, 2015). Transmisi harga pada suatu rantai pemasaran menjadi indikator untuk mengukur kinerja setiap lembaga pemasaran. Dalam hal ini, suatu rantai pemasaran dikatakan efisien dan terintegrasi secara vertikal apabila menunjukkan pola interaksi harga antar lembaga pemasaran mampu ditransmisikan secara simetri (Goodwin, 2006; Ruslan, 2016). Sedangkan transmisi harga dikatakan asimetri (tidak sempurna) apabila informasi harga lambat diterima petani (Sahara \& Wicaksena, 2013; Ashari, 2019).

Pemasaran jagung di Provinsi Gorontalo yang melibatkan lembaga pemasaran pada akhirnya akan mempengaruhi harga jual jagung. Pembentukan harga jagung di tingkat produsen ternyata belum ditansmisikan dengan baik hingga ke tingkat retail/konsumen. Adanya ketidakstabilan harga jagung mengidentifikasikan sistem pemasaran yang tidak efisien.

Berdasarkan Gambar 1, terlihat adanya disparitas harga pada setiap lembaga pemasaran. Pada level produsen dan konsumen, selisih harga jagung relative besar yakni $\mathrm{Rp}$ 2.523/ kg atau sekitar 65 persen. Hal ini terjadi karena mayoritas petani di Provinsi Gorontalo berperan sebagai price taker. Petani memiliki daya tawar yang lemah terkait penetapan harga jagung. Sebaliknya, baik pedagang pengumpul dan eksportir memiliki market power dalam menentukan harga beli jagung. Di sisi lain, struktur pasar yang terbentuk cenderung mengarah ke pasar oligopsoni karena ditemukan lebih banyak jumlah petani dibandingkan jumlah pedagang dan eksportir. Nasution, Asmarantaka, \& Baga (2015) mengungkapkan ketidakseimbangan tersebut menyebabkan pedagang memiliki peranan 


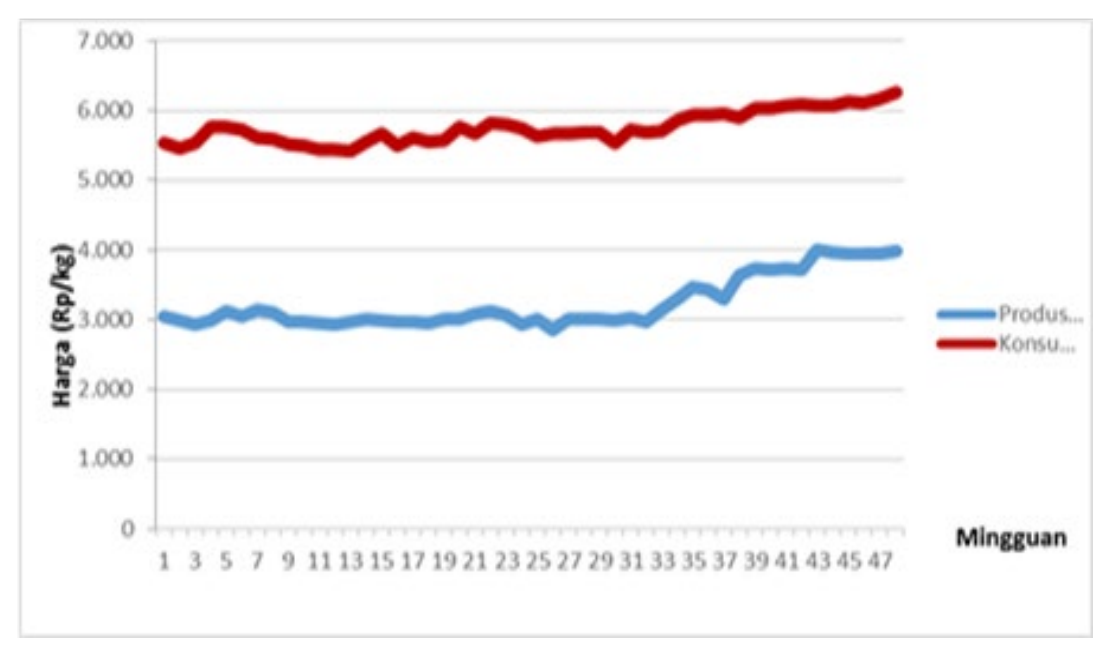

Gambar 1. Harga Jagung Mingguan di Tingkat Produsen
dan Konsumen Provinsi Gorontalo Tahun 2018
Sumber: Badan Ketahanan Pangan Kementrian Pertanian (2016)

yang lebih dominan dan memperkecil peluang petani dalam memperoleh harga yang menguntungkan.

Rendahnya harga yang diterima petani di Provinsi Gorontalo juga disebabkan oleh kondisi jagung yang dipasarkan. Kadar air jagung yang dipasarkan masih belum memenuhi standar dari pedagang meskipun telah diolah dalam bentuk pipilan kering. Hal ini menjadi poin penting terutama bagi eksportir, karena jagung yang dipasarkan diperuntukkan untuk kebutuhan pakan ternak.

Perbedaan market power diduga mengindikasikan inefisiensi dalam pemasaran jagung. Hal ini terlihat dari besarnya disparitas harga tiap lembaga pemasaran. Kondisi tersebut berdampak pada besarnya marjin pemasaran. Disparitas harga pada akhirnya menjadi faktor yang mempengaruhi petani untuk terus menjalankan usahataninya serta menjaga kapasitas produksi jagung khususnya di Provinsi Gorontalo (Sari, Winandi, \& Atmakusuma, 2012).

Berdasarkan uraian tersebut maka penelitian ini dilakukan bertujuan untuk (1). menganalisis integrasi pasar dan transmisi harga jagung antara produsen dan konsumen, (2). menganalisis penyebaran marjin pemasaran pada saluran pemasaran jagung di Provinsi Gorontalo.

\section{METODE}

\section{JENIS DAN SUMBER DATA}

Penelitian ini menggunakan data time series harga mingguan di tingkat produsen dan konsumen selama 148 minggu yaitu dari bulan Maret 2016 hingga Maret 2019. Data tersebut diperoleh dari Badan Ketahanan Pangan (BKP) Kementrian Pertanian, Dinas Pertanian Provinsi Gorontalo, BPS Pusat dan Provinsi Gorontalo, Dinas Perdagangan Provinsi Gorontalo, serta studi pustaka terkait penelitian ini. Selain itu, penelitian ini juga meperoleh data melalui wawancara langsung dengan pelaku pemasaran jagung yang terlibat di Provinsi Gorontalo seperti petani, dan pedagang pengumpul.

\section{LOKASI DAN WAKTU PENELITIAN}

Lokasi penelitian ditentukan secara purposive dengan memilih Kabupaten Pohuwato yang merupakan sentra produksi jagung terbesar di Provinsi Gorontalo tepatnya di Kecamatan Patilanggio. Pelaksanaan penelitian dimulai dari bulan Januari hingga Desember 2020.

\section{METODE PENGAMBILAN SAMPEL}

Populasi meliputi seluruh petani dan pedagang jagung di lokasi penelitian. Metode 
pengambilan sampel petani menggunakan simple random sampling dengan jumlah responden sebanyak 30 petani. Sedangkan pengambilan sampel pedagang berdasarkan alur pemasaran di Kabupaten Pohuwato yang dilakukan dengan teknik snowball sampling.

\section{METODE ANALISIS}

\section{Integrasi Pasar dan Transmisi Harga Jagung}

Sahara \& Wicaksena (2013) menjelaskan bahwa transmisi harga jagung menggunakan Asymmetric Error Correction Model (AECM) dikembangkan oleh Granger \& Engle (1987) dengan tahapan sebagai berikut:

1. Melakukan uji stasioneritas data dan derajat integrasi

2. Menentukan panjang lag (ordo) optimal dengan menggunakan Schwarz Information Criterion (SIC)

3. Melakukan uji kointegrasi terhadap variabel-variabel harga jagung

4. Menentukan arah hubungan sebab-akibat variabel yang digunakan melalui uji kausalitas

5. Mengestimasi model transmisi harga jagung secara vertikal di Provinsi Gorontalo. Adapun model transmisi harga jagung terdiri dari dua persamaan sebagai berikut:

$$
\begin{aligned}
& \Delta P P_{t}=\mu_{1}+\sum_{i=1 \beta_{P P}^{k} \Delta P P_{t-i}+\sum_{i=1}^{k} \beta_{P C} \Delta P C_{t-i}{ }^{+}}^{-}{ }_{\pi 1} Z_{t-1}{ }^{+} \\
& \sum_{i=1 \beta_{P P}^{k} \Delta P P_{t-i}}^{+}+\sum_{i=1 \beta_{P C}^{k} \Delta P C_{t-i}+{ }_{\pi 2}^{+} Z_{t-1}^{+}{ }_{\varepsilon t}}^{+}{ }^{[1]} \\
& \Delta P C_{t}={ }_{\mu}+\sum_{i=1 \beta_{P C}}^{k} \Delta P_{t-i}+\sum_{i=1 \beta_{P P} \Delta P P_{t-i}{ }^{+}}^{+}{ }_{\pi 1 Z_{t-1}}^{+} \\
& \sum_{i=1 \beta_{P C} \Delta P C}^{+}+{ }_{t-i}^{+}+\sum_{i=1 \beta_{P P} \Delta P P t_{t-i}}^{+}{ }_{\pi 2}^{+} Z_{t-1}^{+}{ }_{\varepsilon t}^{+}{ }^{[2]}
\end{aligned}
$$

Keterangan:

$\Delta \mathrm{PP}_{\mathrm{t}} \quad$ : Perubahan harga produsen periode saat ini $(\mathrm{Rp} / \mathrm{kg})$

$\Delta \mathrm{PP}_{\mathrm{t}}^{-} \quad$ : Perubahan penurunan harga produsen periode saat ini $(\mathrm{Rp} / \mathrm{kg})$

$\Delta \mathrm{PP}_{\mathrm{t}-1}{ }^{-}$: Perubahan penurunan harga produsen periode sebelumnya ( $\mathrm{Rp} / \mathrm{kg})$

$\Delta \mathrm{PP}_{\mathrm{t}^{+}} \quad$ : Perubahan kenaikan harga produsen periode saat ini $(\mathrm{Rp} / \mathrm{kg})$
$\Delta \mathrm{PP}_{\mathrm{t}-1}{ }^{+}$: Perubahan kenaikan harga produsen periode sebelumnya $(\mathrm{Rp} / \mathrm{kg})$

$\Delta \mathrm{PC}_{\mathrm{t}} \quad$ : Perubahan harga konsumen periode saat ini $(\mathrm{Rp} / \mathrm{kg})$

$\Delta \mathrm{PC}_{\mathrm{t}}^{-} \quad$ : Perubahan penurunan harga konsumen periode saat ini $(\mathrm{Rp} / \mathrm{kg})$

$\Delta \mathrm{PC}_{\mathrm{t}-1}^{-}$: Perubahan penurunan harga konsumen periode sebelumnya $(\mathrm{Rp} / \mathrm{kg})$

$\Delta \mathrm{PC}_{\mathrm{t}}{ }^{+}$: Perubahan kenaikan harga konsumen periode saat ini $(\mathrm{Rp} / \mathrm{kg})$

$\Delta \mathrm{PC}_{\mathrm{t}-1}{ }^{+}$: Perubahan kenaikan harga konsumen periode sebelumnya $(\mathrm{Rp} / \mathrm{kg})$

$\mathrm{Z}_{\mathrm{t}-1^{+}} \quad$ : ECT di atas garis keseimbangan

$\mathrm{Z}_{\mathrm{t}-1^{-}} \quad$ : ECT bawah garis keseimbangan

$\mu_{1} \quad$ : Intersept

$\varepsilon_{\mathrm{t}} \quad:$ Error term

k : Panjang lag

\section{Saluran dan Marjin Pemasaran}

Saluran pemasaran menggambarkan alur distribusi jagung dari petani sebagai produsen hingga ke tingkat konsumen. Saluran pemasaran yang diteliti melibatkan petani, pedagang pengumpul, eksportir hingga konsumen. Penentuan jumlah saluran pemasaran diawali informasi yang diperoleh dari petani jagung. Selanjutnya dilakukan penelusuran alur distribusi ke lembaga pemasaran lainnya. Analisis saluran pemasaran berdasarkan ukuran panjang pendeknya alur distribusi jagung.

Setelah diketahui saluran pemasaran yang terbentuk, selanjutnya dilakukan analisis marjin pemasaran. Marjin pemasaran dalam penelitian ini diketahui dengan menghitung besar perbedaan harga antar lembaga pemasaran (Asmarantaka, 2012). Secara matematis dapat dituliskan sebagai berikut.

$\mathrm{M}=\mathrm{Ps}-\mathrm{Pb}$

\section{Keterangan:}

$\mathrm{M}=$ Marjin pemasaran antara petani, pedagang, dan eksportir

Ps = Harga jual jagung tingkat petani, pedagang, dan eksportir $(\mathrm{Rp} / \mathrm{kg})$

$\mathrm{Pb}=$ Harga beli jagung tingkat petani, pedagang, dan eksportir $(\mathrm{Rp} / \mathrm{kg})$ 
Selanjutnya dilakukan analisis farmer's share yakni untuk mengukur pangsa harga yang diterima petani relative terhadap harga yang dibayarkan konsumen akhir, dituliskan sebagai berikut (Dahl dan Hammond, 1977).

$F s=\frac{P f}{P r} \times 100 \%$

Keterangan:

$\mathrm{Fs}=$ Farmer's Share

$\mathrm{Pf}=$ Harga jagung yang diterima petani $(\mathrm{Rp} / \mathrm{kg})$

$\operatorname{Pr}=$ Harga jagung yang dibayar konsumen $(\mathrm{Rp} / \mathrm{kg})$

\section{HASIL DAN PEMBAHASAN}

\section{INTEGRASI PASAR DAN TRANSMISI HARGA JAGUNG}

\section{Uji Stasioneritas Data}

Uji stasioneritas (unit root test) merupakan tahap awal dalam ECM untuk membuktikan bahwa data terintegrasi pada ordo yang sama (Oktavia \& Amri, 2017). Pengujian dilakukan menggunakan Augmented Dicky Fuller (ADF). Hasil uji ADF bernilai negatif, semakin besar nilai negatif maka semakin kuat penolakan terhadap hipotesis yang menyatakan bahwa terdapat unit root (tidak stasioner) pada beberapa level pengujian (Imam, Habiba, \& Atanda, 2016). Adapun aturan dalam pengambilan keputusan stasioneritas data sebagai berikut:

1. Nilai t-ADF > nilai kritis Mackinnon maka terima $\mathrm{H}_{0}$, disimpulkan data tidak stasioner

2. Nilai t-ADF < nilai kritis Mackinnon maka tolak $\mathrm{H}_{0}$, disimpulkan data stasioner (Firdaus, 2011; Rusdi, 2011).

Tabel 1. Hasil Uji Stationeritas Data Harga Jagung di Tingkat Produsen dan Konsumen

\begin{tabular}{lrr}
\hline \multirow{2}{*}{ Variabel } & \multicolumn{2}{c}{ Nilai ADF } \\
\cline { 2 - 3 } & Level & First Difference \\
\hline Harga Produsen & $-2,75$ & $-10,45^{* *}$ \\
Harga Konsumen & $-4,29^{* *}$ & $-8,56^{* *}$ \\
\hline${ }^{* *}$ Stationer pada taraf nyata $1 \%$ &
\end{tabular}

Berdasarkan Tabel 1, menunjukkan bahwa hanya harga jagung pada tingkat konsumen yang stasioner pada level. Maka dilanjutkan dengan pengujian pada first difference menunjukkan data harga produsen dan konsumen stasioner pada taraf nyata 1 persen sehingga data dapat digunakan dalam pengujian kointegrasi (Maruddani, Tarno, \& Anisah, 2008).

\section{Panjang Lag (Ordo) Optimal}

Dalam model ECM, penentuan lag optimal artinya menentukan batas jumlah lag dalam analisis data. Hal ini sangat diperlukan karena akan mempengaruhi variabel yang diuji. (Erwandi, Afendi, \& Waryanto, 2019). Pengujian panjang lag memanfaatkan beberapa informasi diantaranya Likelihood Ratio $(L R)$, Akaike Information Criterion (AIC), Schwarz Criterion (SC), dan Hannan-Quinn Criterion (HQ) (Firdaus, 2011).

Tabel 2. Hasil Pengujian Lag Optimal

\begin{tabular}{ccrrrr}
\hline Lag & LogL & \multicolumn{1}{c}{ LR } & \multicolumn{1}{c}{ AIC } & \multicolumn{1}{c}{ SC } & \multicolumn{1}{c}{ HQ } \\
\hline 0 & $-2176,57$ & NA & 30,47 & 30,51 & 30,49 \\
1 & $-1966,92$ & 410,49 & 27,59 & $27,72^{*}$ & $27,64^{*}$ \\
2 & $-1961,86$ & 9,77 & $27,58^{*}$ & 27,79 & 27,66 \\
3 & $-1959,82$ & 3,87 & 27,61 & 27,90 & 27,72 \\
4 & $-1954,46$ & $10,05^{*}$ & 27,59 & 27,96 & 27,74 \\
5 & $-1950,04$ & 8,17 & 27,58 & 28,04 & 27,77 \\
\hline
\end{tabular}

Ket: * lag optimal

Berdasarkan Tabel 2, melihat hasil pengujian keempat kriteria diperoleh lag optimal yang nilainya terkecil dan paling banyak ditemukan pada lag 1. Lag optimal ditunjukkan pada Schwarz Criterion (SC) dan HannanQuinn Criterion $(\mathrm{HQ})$ dengan masing-masing nilai sebesar 27,72 dan 27,64. Nizar (2012) mengungkapkan bahwa semakin panjang lag yang digunakan pada model mengakibatkan hilangnya informasi yang diperlukan dalam analisis data yang disebabkan karena semakin berkurangnya derajat bebas pada model.

\section{Uji Kointegrasi}

Integrasi pasar jagung Provinsi Gorontalo melalui tahapan pengujian kointegrasi. Pengujian ini dimaksudkan untuk membuktikan 
adanya keseimbangan antara data harga jagung di tingkat produsen dan konsumen dalam jangka panjang. Johansen (1995) menjelaskan bahwa sebelum melakukan uji kointegrasi, data harga yang digunakan dalam model stasioner pada first difference (Naidu, Pandaram, \& Chand, 2017).

Tabel 3. Hasil Uji Cointegration Rank (Trace)

\begin{tabular}{lrrrr}
$\begin{array}{c}\text { Hypo- } \\
\text { thesized } \\
\text { No. of CE(s) }\end{array}$ & $\begin{array}{c}\text { Eigen- } \\
\text { value }\end{array}$ & $\begin{array}{c}\text { Trace } \\
\text { Statistic }\end{array}$ & $\begin{array}{c}\mathbf{0 . 0 5} \\
\text { Critical } \\
\text { Value }\end{array}$ & Prob.** \\
\hline None * & 0,21 & 30,39 & 20,26 & 0,00 \\
At most 1 & 0,03 & 3,38 & 9,17 & 0,51 \\
\hline Signifikan pada taraf nyata 5\% & &
\end{tabular}

Berdasarkan Tabel 3, menunjukkan bahwa terdapat satu persamaan yang terkointegrasi artinya memiliki hubungan jangka panjang antar variabel yang digunakan. Kointegrasi antara harga jagung di tingkat produsen dan konsumen mengindikasikan pasar jagung di Provinsi Gorontalo telah terintegrasi. Hal ini sesuai dengan penelitian Adiyoga, Fuglie, \& Suherman (2006) mengungkapkan bahwa data serial harga komoditi yang terkointegrasi secara konsisten menunjukkan adanya hubungan integrasi pasar. Kustiari (2017) juga menjelaskan bahwa uji kointegrasi merupakan uji keterpaduan pasar. Dengan kata lain, data harga yang memiliki hubungan keseimbangan jangka panjang, juga memiliki keterpaduan yang kuat antara pasar produsen dan pasar konsumennya.

\section{Uji Kausalitas}

Uji kausalitas diperlukan untuk mengetahui arah hubungan sebab akibat antara variabel harga jagung di tingkat produsen dan konsumen. Wang (2019) menjelaskan bahwa Granger causality digunakan untuk menguji adanya pengaruh tiap variabel terhadap variabel lainnya sehingga menyebabkan perubahan.

Berdasarkan Tabel 4, menunjukkan nilai probabilitas lebih kecil dari nilai a 5\% artinya harga jagung di tingkat produsen dan harga jagung di tingkat konsumen saling mempengaruhi.
Tabel 4. Hasil uji Granger Causality

\begin{tabular}{|c|c|c|c|}
\hline Hipotesis & Obs & F-statistic & Prob. \\
\hline $\mathrm{PC}_{\mathrm{t}} \rightarrow \mathrm{PP}_{\mathrm{t}}$ & 146 & 5,08 & 0,03 \\
\hline $\mathrm{PP}_{\mathrm{t}} \rightarrow \mathrm{PC}_{\mathrm{t}}$ & & 3,79 & 0,01 \\
\hline
\end{tabular}

\section{Estimasi Model Transmisi Harga}

Transmisi harga asimetri merupakan kondisi yang dihadapi apabila perubahan harga antar level lembaga pemasaran tidak direspon dengan kecepatan dan besaran yang sama. Perbedaan tersebut ditunjukkan dengan adanya shock harga bertanda positif atau negatif yang ditransmisikan dengan kenaikan atau penurunan di sepanjang rantai pemasaran (Vavra \& Goodwin, 2005; Weldesenbet, 2013).

Transmisi harga dalam penelitian ini dibagi menjadi 2 persamaan yakni AECM harga produsen dan harga konsumen jagung. Model ini digunakan untuk melihat penyesuaian perubahan harga jagung pada lembaga pemasaran dari segi kecepatan waktu penyesuaian. Meyer \& von Cramon-Taubadel (2004) mengungkapkan perubahan harga dapat berupa kenaikan atau penurunan harga. Pada waktu yang sama, kenaikan harga di pasar acuan dapat direspon cepat dengan diikuti kenaikan harga di pasar pengikutnya, sedangkan penurunan harga membutuhkan penyesuaian, begitu pula sebaliknya.

Tabel 5. Hasil Estimasi AECM Jagung di Tingkat Produsen dan Konsumen, Maret 2016 - Maret 2019

\begin{tabular}{lcc}
\hline \multicolumn{1}{c}{ Variabel } & $\mathbf{P C}_{\mathbf{t}} \rightarrow \mathbf{P P}_{\mathbf{t}}$ & $\mathbf{P P}_{\mathbf{t}} \rightarrow \mathbf{P} \mathbf{C}_{\mathbf{t}}$ \\
\hline Intercept & $-4,80$ & $-43,66$ \\
$\Delta \mathrm{PP}_{\mathrm{t}}^{-}$ & & $-0,29$ \\
$\Delta \mathrm{PP}_{\mathrm{t}-1}^{-}$ & $0,28^{*}$ & 0,21 \\
$\Delta \mathrm{PC}_{\mathrm{t}}^{-}$ & $-0,02$ & \\
$\Delta \mathrm{PC}_{\mathrm{t}-1}^{-}$ & 0,00 & $-0,24^{*}$ \\
$\Delta \mathrm{PP}_{\mathrm{t}}^{+}$ & & $-0,69$ \\
$\Delta \mathrm{PP}_{\mathrm{t}-1^{+}}$ & 0,21 & $-0,31$ \\
$\Delta \mathrm{PC}_{\mathrm{t}^{+}}$ & $-0,06$ & \\
$\Delta \mathrm{PC}_{\mathrm{t}-1^{+}}$ & $0,07^{*}$ & $-0,03$ \\
$\mathrm{ECT}^{-}$ & $-0,12$ & 0,08 \\
$\mathrm{ECT}^{+}$ & $-0,10$ & 0,45 \\
$\mathrm{R}^{2}$ & 0,14 & 0,11 \\
$\mathrm{R}^{2}$-adj & 0,09 & 0,06 \\
F-test & 0,01 & 0,61 \\
& $(0,91)$ & $(0,44)$ \\
\hline
\end{tabular}

*signifikan pada a $5 \%$ 
Berdasarkan Tabel 5, hasil estimasi model AECM menunjukkan bahwa pada jangka pendek persamaan $\mathrm{PC} \rightarrow \mathrm{PP}$ memiliki nilai elastisitas lebih besar dibandingkan pada persamaan $\mathrm{PP} \rightarrow \mathrm{PC}$. Pada persamaan pertama, penurunan harga di tingkat produsen pada periode sebelumnya bernilai positif sebesar 0,28 dan signifikan pada a $5 \%$. Artinya setiap penurunan harga jagung di tingkat produsen sebesar $10 \%$ menyebabkan penurunan harga di tingkat konsumen sebesar 2,8\%.

Sedangkan pada persamaan kedua, pada saat penurunan harga konsumen pada periode sebelumnya menunjukkan nilai negatif sebesar 0,24 dan signifikan pada a $5 \%$. Artinya setiap penurunan harga jagung di tingkat konsumen pada periode sebelumnya sebesar $10 \%$ menyebabkan kenaikan harga di tingkat produsen sebesar 2,4\%. Dengan demikian, pada jangka pendek terjadi transmisi harga asimetri pada tingkat produsen karena adanya penurunan harga konsumen yang direspon dengan arah yang berbeda di tingkat produsen. Hal ini disebabkan jagung merupakan bahan pangan unggulan di Provinsi Gorontalo sehingga respon perubahan harga cenderung berada pada sisi permintaan dibandingkan penawarannya. Selain itu sebagai produsen, petani memiliki daya tawar yang lemah dalam mempengaruhi harga jagung di pasaran. Sesuai dengan penelitian Muslim (2011), usahatani jagung merupakan salah satu bentuk pasar tidak kompetitif dimana petani cenderung lebih berperan sebagai price taker. Posisi tawar petani yang lemah menyebabkan harga jagung lebih banyak ditentukan oleh para pedagang besar dan industri.

Pada jangka panjang, ditunjukkan oleh nilai $\mathrm{ECT}^{+}$dan ECT- menunjukkan terjadinya penyimpangan harga di atas/bawah garis keseimbangan. Akan tetapi, tidak terdapat nilai ECT yang signifikan pada kedua persamaan. Hal ini membuktikan bahwa harga jagung di tingkat produsen dan konsumen ditransmisikan secara simetri dalam jangka panjang. Sesuai dengan penelitian Jensen \& Moller (2007), menjelaskan bahwa transmisi harga asimetri dapat terjadi pada jangka pen- dek sedangkan pada jangka panjang akan mengalami penyesuaian sehingga transmisi harga menjadi simetri. Hal ini dikarenakan asimetri pada jangka pendek merupakan perwujudan dari adanya penyesuaian dari biaya transaksi yang dikeluarkan meliputi biaya akibat penyimpanan, biaya pembuatan kemasan, serta biaya pencarian informasi (Karantininis, Katrakylidis, \& Persson, 2011; Weldesenbet, 2013). Berdasarkan hasil analisis integrasi pasar dan transmisi harga menunjukkan pemasaran jagung di Provinsi Gorontalo, efisien dari segi harga.

\section{SALURAN PEMASARAN}

Saluran pemasaran jagung di Provinsi Gorontalo melibatkan petani, pedagang pengumpul, dan eksportir. Berdasarkan penelitian ini, saluran pemasaran terbagi menjadi 3 saluran sebagai berikut:

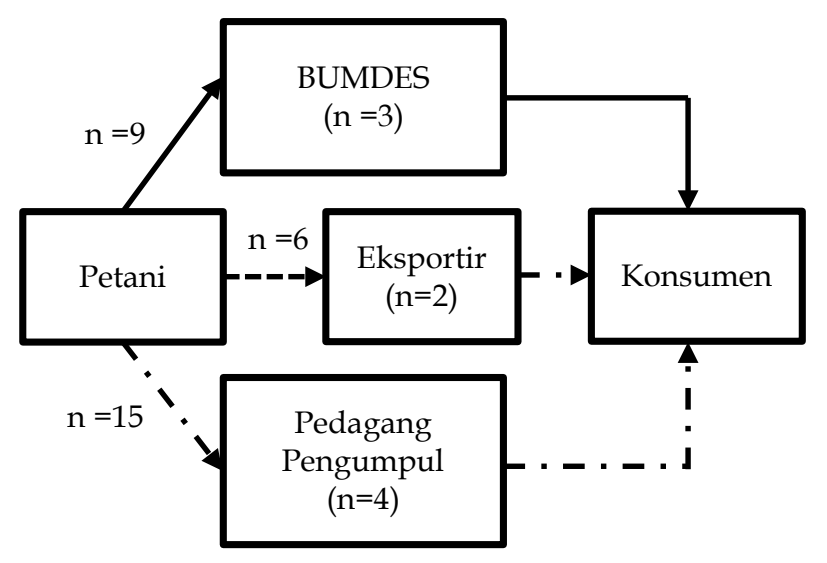

Keterangan :

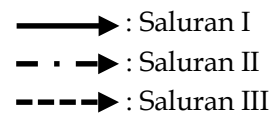

\section{Gambar 2. Saluran Pemasaran Jagung di Provinsi Gorontalo \\ Sumber: Data Primer Setelah Diolah, 2020}

\section{Saluran I: Petani-BUMDES I-Eksportir- Konsumen}

Pada Saluran ini melibatkan 9 orang petani jagung di Desa Dudepo. Petani menjual jagung dalam bentuk pipilan kering ke BUMDES di Desa Dudepo. Sebelum menjual hasil panennya, petani melakukan beberapa fungsi pemasaran meliputi pengeringan, pe- 
mipilan, dan pengangkutan. Kegiatan ini dilakukan untuk menambah nilai jual dari jagung yang dipasarkan.

Selanjutnya, petani menjual jagung tersebut ke BUMDES Dudepo. Rata-rata jumlah produksi jagung yang dijual setiap petani sekitar 4,6 ton/musim tanam. Sebelum dijual lagi ke PT Harim dan PT Seger Agro Nusantara sebagai eksportir jagung, dilakukan pengeringan kembali, dan pengangkutan.

\section{Saluran II: Petani-Pengumpul-Eksportir- Konsumen}

Pada Saluran II, melibatkan 15 orang petani di Desa Suka Makmur. Petani ini juga menjual jagung dalam bentuk pipilan kering dimana sebelumnya dilakukan proses pengeringan, pemipilan, dan pengangkutan ke pedagang pengumpul Desa Suka Makmur. Rata-rata jumlah produksi jagung yang dijual setiap petani sekitar 5,5 ton/musim tanam. Selanjutnya dilakukan pengeringan dan pengangkutan ke eksportir jagung.

\section{Saluran III: Petani-Eksportir-Konsumen}

Pada Saluran III, petani memasarkan jagung secara langsung ke perusahaan eksportir. Petani menjual jagungnya dalam bentuk pipilan kering ke eksportir. Keuntungannya, petani mendapatkan harga lebih tinggi dibandingkan melalui pedagang perantara. Rata-rata jumlah jagung yang dijual setiap petani ke eksportir sekitar 7 ton/musim tanam.

\section{MARJIN PEMASARAN}

Efisiensi pemasaran jagung di Provinsi Gorontalo secara operasional menggunakan marjin sebagai indikator pengukuran. Efisiensi diperoleh apabila nilai marjin pemasaran semakin kecil dan farmer's share yang tinggi (Asmarantaka, 2012).

Besarnya nilai marjin pemasaran dipengaruhi oleh biaya pemasaran dan keuntungan tiap lembaga pemasaran yang terlibat. Perbedaan biaya pemasaran tiap lembaga pemasaran di Provinsi Gorontalo disebabkan karena penerapan fungsi-fungsi pemasaran sebagai berikut:

1. Sortasi/memilah jagung

Sortasi dilakukan untuk memilih jagung dengan kualitas yang baik. Proses sortasi diterapkan oleh BUMDES, pedagang pengumpul, dan eksportir sebelum melakukan pembelian jagung dari petani. Pemilahan jagung didasarkan pada tingkat kebersihan jagung dan kadar air yang dimliki.

BUMDES dan pedagang pengumpul tingkat desa memberikan harga jagung tergantung dari bentuk produk yang dijual. Jagung dalam bentuk pipilan basah dibeli dengan rata-rata harga $\mathrm{Rp} 2.800 / \mathrm{kg}$, dan pipilan kering $\mathrm{Rp} 3.300 / \mathrm{kg}$. Biaya yang dikeluarkan untuk sortasi jagung di tingkat BUMDES ratarata sebesar Rp 11.000/ton, pada pengumpul desa sebesar Rp 13.000/ton.

Sementara itu, pada perusahaan eksportir, harga jagung disesuaikan dengan kadar air yang dimiliki. Jagung pipil dengan kadar air 15-17 persen dibeli dengan harga $\mathrm{Rp}$ $3.500 / \mathrm{kg}$, 18-25 persen dengan harga $\mathrm{Rp}$ $3.400 / \mathrm{kg}$, dan 26-35 persen dengan harga $\mathrm{Rp}$ $3.350 / \mathrm{kg}$. Jagung yang tidak memenuhi standar tersebut akan ditolak perusahaan eksportir. Biaya sortasi pada eksportir ratarata berkisar Rp 117.000-129.000/ton.

\section{Pengeringan}

Proses pengeringan jagung dilakukan semua lembaga pemasaran mulai dari petani hingga eksportir. Setelah panen, petani mengeringkan jagung sebelum dipipil. Proses pengeringan di tingkat petani, BUMDES, dan pedagang pengumpul sangat bergantung pada cuaca.

Pengeringan dilakukan dengan cara menjemur jagung di bawah terik matahari. Petani membutuhkan waktu menjemur sekitar 2-3 minggu. BUMDES dan pedagang melakukan penjemuran kembali selama 2-3 hari hingga kadar air jagung mencapai 14 persen. Biaya yang dikeluarkan BUMDES untuk proses pengeringan rata-rata sebesar Rp 42.000/ton, sedangkan pedagang pengumpul sebesar Rp $50.000 /$ ton. 
Pada eksportir, pengeringan jagung telah menggunakan teknologi yang modern. Pengeringan jagung menggunakan mesin dryer dan hanya membutuhkan waktu setengah hari saja. Biaya yang dikeluarkan untuk proses pengeringan di eksportir berkisar Rp 17.000-22.000/ton.

\section{Pemipilan jagung}

Jagung tongkol yang telah dikeringkan oleh petani, selanjutnya dilakukan pemipilan dengan menyewa mesin pipil dari BUMDES/ pedagang pengumpul. Biaya pemipilan jagung di tingkat petani rata-rata berkisar Rp 78.000-112.000/ton. Pemipilan jagung hanya dilakukan di tingkat petani, dan penjualan jagung dilakukan dalam bentuk pipilan basah dan pipilan kering.

\section{Pengemasan}

Pengemasan jagung yang siap jual dilakukan setelah proses pemipilan. Biaya yang dikeluarkan untuk pengemasan jagung mencakup biaya untuk pengadaan karung dan penggunaan tenaga kerja. Karung yang digunakan untuk mengemas jagung adalah karung beras berukuran $50 \mathrm{~kg}$. Rata-rata biaya pengemasan di tingkat BUMDES sebesar Rp 65.000/ton, dan pedagang pengumpul sebesar Rp 74.000/ton.

\section{Pengangkutan}

Pengangkutan jagung dilakukan kelompok pedagang dengan mengunjungi petani untuk membeli jagung. Jagung yang telah disortasi dan dikemas, selanjutnya diangkut oleh pedagang menggunakan mobil pick up. Biaya pengangkutan mencakup biaya bahan bakar kendaraan dan tenaga kerja. Biaya pengangkutan yang dikeluarkan BUMDES dan pedagang pengumpul, rata-rata sebesar Rp 80.000/ton. Sedangkan tingkat eksportir, biaya pengangkutan cukup besar rata-rata berkisar Rp 133.000-146.000/ton. Hal ini disebabkan karena perusahaan tersebut mengangkut jagung ke kantor pusat untuk kemudian diekspor dalam bentuk pakan ternak. Pengangkutan jagung menggunakan mobil kecil dengan kapasitas muatan $\pm 2-3$ ton, mobil besar/kontainer memuat \pm 10 ton.

\section{Penyimpanan}

Perusahaan eksportir yakni PT Harim dan PT Seger Agro Nusantara merupakan perusahaan yang memiliki fasilitas gudang penyimpanan jagung dengan kapasitas besar. Perusahaan ini mengumpulkan jagung dalam bentuk pipilan kering dari berbagai supplier (petani, pedagang) di wilayah Gorontalo. Perusahaan tersebut bergerak dalam pengadaan dan pendistribusian produk jagung dengan tujuan ekspor. Penyimpanan dilakukan 1-2 minggu hingga selanjutnya didistribusikan ke kantor pusat untuk diolah menjadi pakan ternak. Rata-rata biaya penyimpanan berkisar Rp 500.000-625.000/ton.

Berdasarkan Tabel 6, nilai marjin yang tinggi ditunjukkan pada Saluran I dan II masing-masing memiliki marjin sebesar Rp $2.822 / \mathrm{kg}$ dan $\mathrm{Rp} 2.923 / \mathrm{kg}$. Keuntungan lembaga pemasaran paling tinggi diperoleh eksportir. Perbedaan marjin ketiga saluran disebabkan karena pada saluran tersebut diterapkan fungsi-fungsi pemasaran yang menyebabkan adanya biaya pemasaran sehingga mempengaruhi harga jual jagung.

Biaya pemasaran terkecil berada pada saluran III yakni sebesar Rp $817 / \mathrm{kg}$, dengan nilai marjin terendah sebesar $\mathrm{Rp} 2.417 / \mathrm{kg}$. Maka dari itu, Saluran III merupakan saluran pemasaran jagung yang paling efisien dengan farmer share sebesar $57,60 \%$. Pada saluran ini, petani memasarkan jagungnya langsung ke perusahaan eksportir. Pratama \& Nuswantara (2020), mengungkapkan tingginya farmer share menjadi dorongan bagi petani jagung untuk terus melakukan kegiatan usahatani karena memberikan keuntungan bagi petani.

Dengan demikian, dapat disimpulkan bahwa pemasaran jagung di Provinsi Gorontalo menunjukkan efisiensi dari segi harga dan operasional. Efisiensi harga terlihat dari terintegrasinya pasar jagung antara level produsen dan konsumen, diikuti dengan perubahan harga jagung yang mampu ditransmisikan secara simetri dalam jangka panjang. Efisiensi dari segi harga sejalan 
dengan operasional pemasaran jagung. Secara operasional, kegiatan pemasaran mampu memberikan keuntungan bagi tiap lembaga pemasaran dan nilai marjin yang rendah dan farmer's share yang tinggi.

Tabel 6. Analisis Marjin Pemasaran Jagung Provinsi Gorontalo

\begin{tabular}{|c|c|c|c|c|}
\hline \multirow{2}{*}{ No } & \multirow{2}{*}{ Uraian (Rp/Kg) } & \multicolumn{3}{|c|}{ Saluran Pemasaran } \\
\hline & & 1 & 2 & 3 \\
\hline \multirow[t]{6}{*}{1} & Petani & & & \\
\hline & Biaya pemasaran** & 102 & 144 & 90 \\
\hline & *Biaya pengeringan & 7 & 28 & 5 \\
\hline & *Biaya pemipilan & 80 & 112 & 78 \\
\hline & *Biaya pengangkutan & 15 & 4 & 7 \\
\hline & Harga Jual & 3.111 & 3.077 & 3.283 \\
\hline \multirow[t]{10}{*}{2} & BUMDES & & & \\
\hline & a. Harga Beli & 3.111 & & \\
\hline & b.Biaya pemasaran & 198 & & \\
\hline & *Biaya Sortasi & 11 & & \\
\hline & *Biaya pengeringan & 42 & & \\
\hline & *Biaya pengemasan & 65 & & \\
\hline & *Biaya pengangkutan & 80 & & \\
\hline & c. Harga Jual & 3.500 & & \\
\hline & d. Keuntungan & 191 & & \\
\hline & e. Margin & 389 & & \\
\hline \multirow[t]{10}{*}{3} & Pengumpul Desa & & & \\
\hline & a. Harga Beli & & 3.077 & \\
\hline & b.Biaya pemasaran & & 217 & \\
\hline & *Biaya Sortasi & & 13 & \\
\hline & *Biaya pengeringan & & 50 & \\
\hline & *Biaya pengemasan & & 74 & \\
\hline & *Biaya pengangkutan & & 80 & \\
\hline & c. Harga Jual & & 3.650 & \\
\hline & d. Keuntungan & & 356 & \\
\hline & e. Margin & & 573 & \\
\hline \multirow[t]{11}{*}{4} & Eksportir & & & \\
\hline & a. Harga Beli & 3.500 & 3.550 & 3.283 \\
\hline & b.Biaya pemasaran & 965 & 985 & 817 \\
\hline & *Biaya Sortasi & 128 & 129 & 117 \\
\hline & *Biaya pengeringan & 21 & 22 & 17 \\
\hline & *Biaya pengemasan & 61 & 63 & 50 \\
\hline & *Biaya pengangkutan & 144 & 146 & 133 \\
\hline & *Biaya penyimpanan & 611 & 625 & 500 \\
\hline & c. Harga Jual & 5.933 & 5.900 & 5.700 \\
\hline & d. Keuntungan & 1.468 & 1.365 & 1.600 \\
\hline & e. Margin & 2.433 & 2.350 & 2.417 \\
\hline \multirow[t]{6}{*}{5} & Konsumen & & & \\
\hline & Harga Beli & 5.933 & 5.900 & 5.700 \\
\hline & Total Biaya pemasaran & 1.163 & 1.202 & 817 \\
\hline & Total Keuntungan & 1.659 & 1.721 & 1.600 \\
\hline & Total Margin & 2.822 & 2.923 & 2.417 \\
\hline & Farmer Share & 52,44 & 52,15 & 57,60 \\
\hline
\end{tabular}

Sumber: Data Primer Setelah Diolah, 2020

\section{KESIMPULAN DAN SARAN}

\section{KESIMPULAN}

Hasil penelitian disimpulkan sebagai berikut:

1. Pada jangka pendek ditemukan transmisi harga asimetri di tingkat produsen dan konsumen. Sebaliknya, perubahan harga ditransmisikan secara simetri pada jangka panjang menunjukkan integrasi pasar sehingga disimpukan pemasaran jagung efisien dari segi harga.

2. Marjin pemasaran terkecil berada pada Saluran III, dimana pemasaran dilakukan secara langsung ke eksportir. Pemasaran jagung di Provinsi Gorontalo memberikan nilai farmer share yang tinggi, sehingga disimpulkan bahwa pemasaran bersifat efisien dari segi operasional.

\section{SARAN}

Adapun saran dalam penelitian ini adalah sebagai berikut:

1. Sebaiknya petani meningkatkan kualitas jagung dengan melakukan kegiatan pasca panen sehingga harga jagung yang dipasarkan menjadi lebih tinggi.

2. Sebaiknya pemerintah Provinsi Gorontalo membentuk kelembagaan pemasaran jagung di tingkat Desa yang memudahkan petani memperoleh informasi pasar.

3. Untuk penelitian selanjutnya diharapkan menambah jumlah data harga jagung mingguan, dengan menganalisis setiap level lembaga pemasaran.

\section{DAFTAR PUSTAKA}

Adiyoga, W., Fuglie, K. O., \& Suherman, R. (2006). Integrasi Pasar Kentang di Indonesia: Analisis Korelasi dan Kointegrasi. Informatika Pertanian, 15(1), 835-852.

Ashari, U. (2019). Transmisi Harga Asimetri Udang Beku Antara Indonesia dan Amerika Serikat. Jurnal Ideas Publishing, 5(1), 63-75.

Asmarantaka, R. W. (2012). Pemasaran Agribisnis (Agrimarketing). Bogor: IPB Press.

Astuti, T. W., Maharani, E., \& Yusmini. (2016). Fungsi-Fungsi Pemasaran Jagung Manis di Desa Ridan Permai Kecamatan 
Bangkinang Kabupaten Kampar. Jom Faperta, 3(2), 1-9.

Badan Ketahanan Pangan Kementrian Pertanian. (2016). Harga Jagung Mingguan Provinsi Gorontalo Tahun 2018. Retrieved March 20, 2019, from http:// panelhargabkp.pertanian.go.id/2 016/

Badan Pusat Statistik. (2016). Produksi, Luas Panen, Produktivitas Jagung Menurut Provinsi, 1993-2015. Retrieved February 27, 2019, from https:// www.bps.go.id

Erwandi, Afendi, F. M., \& Waryanto, B. (2019). Analisis Pengaruh Daerah Pemasok Terhadap Harga Cabai Merah di DKI Jakarta menggunakan Vector Error Correction Model (VECM). Indonesian Journal of Statistics and Its Applications, 3(3), 216-235. https://doi.org/10.29244/ijsa.v3i3.276

Firdaus, M. (2009). Manajemen Agribisnis. Jakarta: PT Bumi Aksara.

Firdaus, M. (2011). Aplikasi Ekonometrika untuk Data Panel dan Time Series. Bogor: IPB Press.

Goodwin, B. K. (2006). Spatial and vertical price transmission in meat markets. Paper Presented at Workshop of Market Integration and Vertical and Spatial Price Transmission in Agricultural Markets. Kentucky (US): University of Kentucky.

Granger, C. W. J., \& Engle, R. F. (1987). Cointegration and Error Correction: representation, estimation, and testing. Econometrica, 55, 251-276.

Imam, A., Habiba, D., \& Atanda, B. T. (2016). On Consistency of Test for Stationarity in Autoregressive and Moving Average Models of Different Orders. American Journal of Theoretical and Applied Statistics, 5(3), 146-153. https://doi.org/10.11648/j.ajtas.2016050 3.20

Jensen, J. D., \& Moller, A. S. (2007). Vertical Price Transmission in the Danish Food Marketing Chain. Working Paper.
Institute of Food and Resource Economics, Copenhagen.

Karantininis, K., Katrakylidis, K., \& Persson, M. (2011). Price Transmission in the Swedish Pork Chain: Asymmetric non linear ARDL. Paper Presented at the EAAE 2011 Congress. Zurich, Switzerland.

Kustiari, R. (2017). Perilaku Harga dan Integrasi Pasar Bawang Merah di Indonesia. Jurnal Agro Ekonomi, 35(2), 7787. https://doi.org/10.21082/jae.v35n2

Kusumaningsih, A. (2015). Analisis Integrasi Vertikal Pasar Beras di Indonesia. Buletin Bisnis Dan Manajemen, 1(2), 130-141.

Maruddani, D. A., Tarno, \& Anisah, R. A. (2008). Uji Stasioneritas Data Inflasi Dengan Phillips-Perron Test. Media Statistika, 1(1), 27-34.

Meyer, J., \& von Cramon-Taubadel, S. (2004). Asymmetric Price Transmission: A Survey. Journal of Agricultural Economics, 55(3), 581-611. https:// doi.org/10.1111/j.14779552.2004.tb00116.x

Muslim, A. (2011). Elasticity of Corn Price Transmission and Its Implication to Farmers. Economic Journal of Emerging Markets, 3(1), 77-85.

Naidu, S., Pandaram, A., \& Chand, A. (2017). A Johansen Cointegration Test for The Relationship between Remittances and Economic Growth of Japan. Modern Applied Science, 11(10), 137-151. https://doi.org/10.5539/mas.v11n10p1 37

Nasution, A. H., Asmarantaka, R. W., \& Baga, L. M. (2015). Efisiensi Pemasaran Gambir Di Kabupaten Lima Puluh Kota, Sumatera Barat. Buletin Ilmiah Litbang Perdagangan, 9(2), 221-239. https://doi.org/10.30908/bilp.v9i2.9

Nizar, M. A. (2012). Dampak fluktuasi harga minyak dunia terhadap perekonomian Indonesia. Buletin Ilmiah Litbang Perdagangan, 6(2), 189-210. https://doi.org/10.30908/bilp.v6i2.131 
Oktavia, N. E., \& Amri. (2017). Analisis Kausalitas antara Inflasi dan Konsumsi di Indonesia. Jurnal Ilmiah Mahasiswa, 2(1), 164-175.

Pratama, Y. Y., \& Nuswantara, B. (2020). Analisis Pemasaran Kacang Tanah di Kecamtan Pabelan Kabupaten Semarang. Jambura Agribusiness Journal, 2(1), 34-38. https://doi.org/10.37046/jaj.v2i1.7042

Purwasih, R., Firdaus, M., \& Hartoyo, S. (2017). Transmisi Harga Jagung di Provinsi Gorontalo. Jurnal Agribisnis Indonesia, 5(1), 75-88. https://doi.org/10.29244/jai.2017.5.1.75 $-88$

Rahmi, E., \& Arif, B. (2012). Analisis Transmisi Harga Jagung sebagai Bahan Pakan Ternak Ayam Ras di Sumatera Barat. Jurnal Peternakan Indonesia, 14(2), 343348.

https://doi.org/10.25077/jpi.14.2.343348.2012

Rusdi. (2011). Uji Akar-Akar Unit dalam Model Runtun Waktu Autoregresif. STATISTIKA: Journal of Theoretical Statistics and Its Applications, 11(2), 67-78.

Ruslan, J. A. (2016). Transmisi harga dan perilaku pasar bawang merah [tesis]. Bogor: Sekolah Pascasarjana, Institut Pertanian Bogor.

Sahara, \& Wicaksena, B. (2013). Asymetry in Farm-Retail Price Transmission: The Case of Chili Industry in Indonesia. Jurnal Ekonomi Dan Kebijakan Pembangunan, 2(1), 1-13. https://doi.org/10.29244/jekp.2.1.1-13

Sari, I. N., Winandi, R., \& Atmakusuma, J. (2012). Analisis Efisiensi Pemasaran Jagung di Provinsi Nusa Tenggara Barat. Forum Agribisnis, 2(2), 191-210. https://doi.org/10.29244/fagb.2.2.191210

Surbakti, M. N., Darus, H. M. B., \& Chalil, D. (2015). Analisis faktor-faktor yang mempengaruhi harga jagung pipil ditingkat produsen Sumatera Utara. Journal of Agriculture and Agribusiness Socioeconomics, 2(8), 15106.
Vavra, P., \& Goodwin, B. K. (2005). Analysis of Price Transmission Along Food Chain. Working Papers OECD Food, Agriculture and Fisheries. No 3, OECD Publishing.

Wang, X. (2019). A Granger Causality Test of the Causal Relationship Between The Number of Editorial Board Members and The Scientific output of Universities in The Field of Chemistry. Current Science, 116(1), 35-39.

Weldesenbet, T. (2013). Asymmetric price transmission in the Slovak liquid milk market. Agricultural Economics, 59(11), 512-524.

https://doi.org/10.17221/150/2012-

AGRICECON 